\title{
Local Government Functions in Improving the Quality Health
}

\author{
Siti Normi, SE, M. Si \\ University lecturer Methodist Indonesia
}

Received: February 26, 2017 Accepted: March 26, 2017 Published: March 28, 2017

doi: 10.5296/jsss.v4i2.10994 URL: http://doi.org/10.5296/jsss.v4i2.10994

\begin{abstract}
The local government in improving health care visits of policy instruments used by local governments is mandatory instruments. This required the use of instruments is evident from the role of government in health care without the intervention of the private sector. The supporting factors consist of: full support financing of medical facilities and the cost of hospital operations, the rules on which the service work and visit patients continued to increase from year to year. While the factors that may hinder the improvement of the quality of health care include: unbalance the ratio between the number of medical patients, the still small site allowance for hospital employees, they still lack the human resources development program, and the limited facilities and infrastructure of the hospital.
\end{abstract}

Keywords: Local government, Service quality, Health

\section{Introduction}

Since the implementation of Law No. 29, 1999 revised by the Act No. 322004 there has been a shift in the implementation of public administration in Indonesia which initially adheres to the principle centralized to decentralized. With the implementation of this decentralized system of local governments have the authority to regulate and administer governmental affairs and public interests at its own initiative based on the aspirations of the people in accordance with the legislation.

Hoessein (Muluk, 2007) reveals that desentrali- SASI includes two main elements. First, the establishment of autonomous regions, and second, delivery of government affairs for the autonomous region. From The second main element is then born what is referred to as a local government.

In Indonesian affairs division between the central government and local government governed by Law 32 of 2004 and No. 38 in 2007. Under Law 32 of 2004 and No. 382007 affair be a government authority is divided into obligatory functions and affairs of choice. Obligatory is the government affairs shall be convened by the provincial government and 
district / city, related to basic services, such as education, health, environment and others. While the affairs of government affairs selection is obviously there and the potential to improve the welfare of society in accordance with the conditions, peculiarities, and potential in the regions concerned, for example, marine and fisheries, forestry, agriculture and others.

It is understandable that health services are included in the obligatory functions that must be held by local governments in order to improve the welfare of people in the health sector in the region. According to Stewart (1995) one of the important characteristics that distinguish the local authority of private sector organizations is that the public not only as customers but also as citizens. If they are respected as customers, they also respected as citizens. There is a dual responsibility of the local authorities in providing services to the community.

Public services including health sector by government officials today there are still many weaknesses that can not be found meet the quality expected by society. Services provided too convoluted with reasons in accordance with procedures, the number of charges and the cost of a very long time, so the service provided tends to be ineffective and inefficient. It is characterized by the presence of public complaints submitted through the mass media, which can result in unfavorable image of the government apparatus. Indonesian Research Institute for Civil Society (INCIS) conducted on 480 respondents in Jakarta produce that performance of public services provided by local governments has not been satisfactory. (Sinambela, 2007).

The low quality of public services in the various regions showed still not maximal efforts of local authorities in improving service quality. Within the framework of the regional autonomy policy, services to the public health sector is one of the tasks that have been decentralized local governments by the central government (Article 22 of Law No. 32 in 2004). The local government has the authority to regulate its own system of government and household in the field health by choosing policies that suit the needs and capabilities of the region. The regional authority is a logical consequence to achieve the effectiveness of service management, as well as a responsibility that must be implemented seriously by the local government. This shows the magnitude of the role of local governments in the provision of health services so there must be an effort of the local government to improve the quality of health services.

But the reality of the field of health care in the region can not meet the expectations of society. Based on the survey results of non-governmental organizations community partnerships, Regional Studies and Information Center and the Coalition People's Anti Impoverishment Movement (Tuesday, 25 September 2008) involving 400 respondents in 115 villages in 42 districts in Jakarta, revealed that nearly $65 \%$ of respondents gave a minus value to every aspect of services including health services. Most cardholders poor families still difficult to get health care services. Some of them are obliged to pay $25-35 \%$ of the total cost of care. (Kompas, Wednesday, November 26, 2008).

According Sekeon (2004) in his research on the Ministry Health stated that in general the health problems facing the region today as differences in health status between regions is still high, the poor quality of health among the poor, the double burden of disease. Low quality, quantity, equity and affordability of healthcare is the real challenge faced during the era of regional autonomy. In addition, health services are also faced with the lack of environmental 
health, and health financing issues. On the one hand visible magnitude of the problems facing the region but on the other hand implied the weak capacity of local governments, especially at the level of district / city.

\section{Decentralization and Local Government}

The definition given to the word "decentralization" is very diverse. Rondinelli and Cheema was quoted Dwiyanto (2006) understands widely decentralization, ie the transfer of authority or power sharing in government planning and management and decision-making from the national to the local level.

Slightly different from the opinions Rondinelli above, according to United Nations (UN) process can be done by delegating authority to officials outside the capital (deconcentration) or to the office or an autonomous institution at the local level (Devolution). With deconcentration means there is a device region that is outside the central office. Central departments delegate authority and responsibility for specific areas of administrative nature to those officials who are in the region / area without handing over power fully to a final accountability remain the central departments. While in devolution, some powers given to the political bodies in the area are the full authority to take decisions both politically and administratively. (Dwiyanto, 2006).

Furthermore, the Act No. 322004 decentralization of government is defined as the delegation of authority by the government to autonomous regions to set up and administer governmental affairs in the Unitary State of the Republic of Indonesia.

In the framework of decentralized, autonomous regions are outside the organizational hierarchy of the central government, while in the field deconcentration hirearchy administration are in government organizations navel. Desentralisation shows the pattern of relationship between organizational authority. Although the relationship between local government and the government is the relationship between organizations, but the local government (elapsed areas in autonomous) government creation. Therefore, the existence of local government is dependent and subordinate to the government. In contrast to decentralization, deconcentration bore pattern of power relations, intra-organization.

Hoessein as quoted Muluk (2007) reveals that the decentralization includes two main elements. First, the establishment of autonomous regions, and secondly, the delivery of government affairs for the autonomous region. The principal elements of the second and was born what is referred to as a local government.

The regional governments (local government) according to the United Nations (1961), quoted by Meenakshisundaram in (Jha \& Mathur, 1999) is a political sub-division in a nation (in a federal state, in the US), which is formed above the law and have the authority full over local affairs including in collecting taxes and use local workforce for a particular purpose and determined by election officials.

Hoessein (2007), revealed that the local government is a concept that can contain three meanings. First, it means that local governments are often interchangeable with the local authority which refers to the organ, the council and the mayor and the recruitment of officers is based on the selection. Secondly, he referred to the local government conducted by the local government. This second meaning, it refers to the function. In determining the functions 
under the authority of the local government, using the principle of ultra vires doctrine and general competence or open-end arrangement. The ultra vires doctrine shows that local governments may act on certain things or provide certain services. Or a function of government affairs for the local government specified while the remaining functions of government into the competence of the central government. The principle of general competence or open-end arrangement, which means that local governments should do whatever is necessary to meet regional needs as determined by the decision makers in the area. The central government has had affairs or detailed functionality, while the remainder is a function or affairs which are the responsibility of local governments (Hoessein \& Smith, as quoted by Muluk, 2007). Third, it means the autonomous regions: Hoessein as quoted Muluk, (2007) explains that the establishment of an autonomous region that is simultaneously the birth of autonomous status based on the aspiration and objective conditions of the people residing in certain areas as part of the nation and the national territory, Communities demanding autonomy through decentralization transformed into an autonomous region as a unit of community authorized to regulate and administer affairs according to its own initiative based on the aspirations of the people.

\section{Role of Local Governments}

Meenakshisundaram (Jha \& Mathur, 1999) describes some of the role of local government (the roles of local government) that can be found in the system of decentralized government. The role of local government in question, as follows:

a. Being an effective weapon in the face of local pressure to accommodate and articulate local interests, become a medium of political education for the people who feel the direct implementation of government functions.

b. Because of its proximity in location, in the provision of services can take place more efficiently.

c. Planning can be better because more aware of local conditions, with the use of local labor more efficient anyway.

d. Government officials responsible for the better because closer relations with the public.

e. The local government can be an effective medium of communication between the central and local communities related to the central government in the regions.

Associated with the government's role in the provision of public services then there are some matters that fall under the authority area in order to run their own affairs rumahtanggnaya. Under Law No. 322004 affair became the regional authority includes the obligatory functions and affairs of choice.

Mandatory government affairs is a government affairs relating to basic services including: planning and development control; planning, utilization and monitoring system room; organizing public order and public tranquility; the provision of public infrastructure; handling the field of health; providing education and allocation of human resources potential; tackling social problems; the field of employment services; facilitating the development of cooperatives, small and medium enterprises; environmental control; land services; population and civil registration services; general administrative services administration; administration of capital investment services; implementation of other basic services; Other obligatory 
functions mandated by legislation.

Government affairs that are closely related to the selection of excellent potential and uniqueness of the area. This selection includes business affairs government that actually exists and has the potential to increase public welfare in accordance with the conditions, peculiarities and potential in the regions concerned, among others, mining, fisheries, agriculture, plantation, forestry and tourism.

Next in PP 38 in 2007 in more detail again affair that became the regional authority which is divided into obligatory functions and affair choice.

Obligatory is the government affairs shall be convened by the provincial government and district / city, related to basic services. These matters include: education; health; living environment; public Works; spatial planning; development Planning; housing; youth and sport; capital investment; cooperatives and small and medium enterprises; population and civil registration; employment; food security; empowerment of women and protection of children; family planning and family welfare; transportation; communication and informatics; land; political unity of the nation and the country; regional autonomy, public administration, financial administration area, the region, staffing, and coding; empowerment of communities and villages; social; culture; statistics; archives; and a library.

While the affairs of government affairs selection is obviously there and the potential to improve people's welfare in accordance with the conditions, peculiarities, and excellent potential areas concerned. Affairs of these options include: marine and fisheries; agriculture; forestry; energy and Mineral Resources; tourism; industry; trading; and transmigration.

Under Law No. 32 in 2004 and No. 38 In 2007, the health services, including obligatory obligatory local government organized by the provincial government and district / city. Within the framework of the regional autonomy of local government authority to regulate the affairs of government that is both localities own initiative based on the aspirations of the people. Thus decentralization actually embody the autonomy of local communities to solve the problems and the provision of services that are locality for the welfare of the community. Therefore, community involvement is very important in providing feedback about quality of care they received in order to determine the quality of public services is not only determined by the government or agencies that provide services (providers), but is determined jointly between the provider to the user, customer, client, or citizen as a community of service users. (Supriyono, 2002).

\section{Public Service}

Services can basically be defined as the activity of a person, group or organization directly or indirectly to meet the needs. (Pasolong, 2007).

Moenir states that the service is meeting the needs of the process through the activities of others directly. while Minister

Administrative Reform, argued that the service is all forms of service activities in the form of goods or services in an effort to meet the needs of the community. (Pasolong, 2007).

Meanwhile, the term is derived from the English public, which means general public, society and the State. The word public is already accepted into Indonesian Baku became public, which means the public, crowds, crowded. Inu Kencana defines public is a man who has a 
unity of thought, feelings, expectations, attitudes and actions are right and good by values and norms that feels it has. Therefore, the public service is defined as any activity undertaken by the government on a number of human beings who have any remunerative activity in a collection or entity, and offers a satisfaction even though the results are not tied to a physical product. (Sinambela, 2007).

Public service according Sinambela (2007) is any activity undertaken by the government on a number of human beings who have any remunerative activity in a collection or entity, and offers a satisfaction even though the results are not tied to a physical product.

Agung Kurniawan states that public service is the provision of services (airport) needs of others or society The organization has an interest in accordance with the basic rules and procedure adopted. (Kurniawan as quoted by Pasolong, 2007).

Meanwhile, the notion of public service by PAN Decree No. 25 of 2004 is all the service activities undertaken by public service providers in an effort to meet the needs of service recipients, as well as in the implementation of the provisions of the legislation. (Sinambela, 2007).

Thus, the public service is an effort to fulfill the wishes and needs of the community by government officials in order the implementation of the statutory provisions in force.

\section{Health Services}

PAN Decree No. 582002 classifies public services into three, namely: administrative services, services of goods and services. services is defined as the type of services provided by the service unit in the form of facilities and pre and supporting facilities. The final product in the form of services that bring benefits to the recipient directly and used up within a certain period. (Pasolong, 2007).

Based on these definitions, it can be understood that the health service is included in the form of services. As for health care, according to Levey and Loomba (as quoted by Azwar, 1996: 35 ) is the efforts conducted alone or together in an organization to maintain and improve health, prevent and cure disease and restore the health of individuals, families, groups and or community.

In accordance with these limits, it can be understood that the shape and type of health services can be found many kinds. According to Azwar (1996) differences in the shape and type of health services generally determined by: 1) Organizing services, whether carried out individually or together in an organization; 2) The scope of activities, would only cover the maintenance of health, improving health, disease prevention, cure disease, health recovery or a combination thereof; 3) Target health services, whether for individuals, families, groups or to society as a whole.

In more detail, according leavel and Clark (Azwar, 1996) there are differences between the two forms of health care, which can simply be described in the following table: 
Differences in Medicine with the Health Care Services community

\begin{tabular}{|l|l|}
\hline MEDICAL SERVICES & PUBLIC HEALTH SERVICES \\
\hline 1. Power is executing especially doctors & $\begin{array}{l}\text { 1. Power executing especially public health } \\
\text { experts }\end{array}$ \\
\hline 2. The main focus on the healing of disease & 2. The main focus on disease prevention \\
\hline 3. The main target is the individual or family & 3. The main target is society as a whole \\
\hline $\begin{array}{l}\text { 4. Lack of attention to efficiency } \\
\text { 5. There should not attract attention because } \\
\text { it is contrary to medical ethics }\end{array}$ & $\begin{array}{l}\text { 4. Always try to find an efficient way } \\
\text { as health education }\end{array}$ \\
\hline $\begin{array}{l}\text { 6. Run the individual functions and are bound } \\
\text { by law }\end{array}$ & $\begin{array}{l}\text { 6. Run the function by organizing the } \\
\text { community and got support legislation }\end{array}$ \\
\hline $\begin{array}{l}\text { 7. The income earned from reward } \\
\text { 7. Responsible only to sufferers }\end{array}$ & $\begin{array}{l}\text { 7. Income in the form of salary from the } \\
\text { government }\end{array}$ \\
\hline $\begin{array}{l}\text { 9. Unable to monopolize health efforts and } \\
\text { even got rival }\end{array}$ & 9. Responsible for the entire community \\
\hline $\begin{array}{l}\text { 10. The administrative problem is very } \\
\text { simple. }\end{array}$ & 10. Faced with the issue of leadership \\
\hline
\end{tabular}

Source: Azwar, 1996.

Based on the shape and type of health services over the health services referred to in this article is part of a public health service that can be seen from the target community as a whole, earnings in the form of salaries of government employees and can monopolize health efforts.

\section{Quality of Public Services}

The word quality has many different definitions and ranging from the conventional to the more strategic. The conventional definition of quality is usually directly describe the characteristics of a product, such as: performance (performance), reliability (reliabity), easy to use (ease of use), and aesthetics (esthetics). (Sinambela, 2007).

As for the strategic definition states that quality is everything that is able to meet the desires or needs of customers (meeting needs of customers). (Sinambela, 2007).

Based on the notion of quality, both conventional and more strategic by Gaspersz in Sampara Lukman (Sinambela, 2007) suggests that basically refers to the notion of quality principal: 1) the quality of the product consists of a number of features, either privileges directly or attractive feature that meets the needs of customers and provide satisfaction with the use of the product; 2) the quality made up for everything that is free from flaws or damage.

Quality for services provided of course the quality is meant to be fulfilled. Developing countries generally can not be meet both of these qualities so lacking public services satisfactory. 
Frederickson is a pioneer of New Public Administration (1988) states: New State Administration tried in the same way to demand changes that will increase the target - good management, efficiency, economy, and social justice.

This theory is substantially revealed that quality public services, namely: a) The services with good management, emphasis on setting (management) of public services; b) Efficiency, emphasizes the provision of better services to the resources available; c) Economical, emphasizing the provision of services as cheaply as possible and within reach of the public (users of services); d) Social justice, emphasizing equality in government services; e) Carrying more responsive to the needs of citizens rather than to the needs of public organizations.

New Public Administration who pioneered by Frederickson more emphasis on normative theories, philosophical and activism. It is widely discussed is regarding the values, ethics, social justice, the relationship between the bureaucracy and the entity served as well as broad issues such as urbanization, technology and violence. The new thing that became the emphasis of this movement is morally, and therefore not a neutral administration. The new public administration assumes the existence of a number of values that must be actualized that have structural and managerial implications. In New Public Administration there is some value to be achieved in the public service, namely: responsiveness (responsiveness), worker and citizen participation in decision-making, social justice, the choice of citizens, and administrative responsibility for the program's effectiveness.

\section{Conclusion}

Public services are given a broad sense, meaning not only limited to the provision of basic services to the people but also of all government activities carried out either directly or indirectly in order to meet the public interest. Public service has always been associated with an activity undertaken of a person or group of persons or particular institutions to provide assistance and convenience to the public in order to meet certain goals. Public services have become increasingly important as always with the public that has a diversity of interests and goals.

The low quality of public services in the various regions showed still not maximal efforts of local authorities in improving service quality. Within the framework of the regional autonomy policy, services to the public health sector is one of the tasks of local government that has been decentralized by the central government (Article 22 of Law No. 32 in 2004). The local government has the authority to regulate its own system of government and household in the field health by choosing policies that suit the needs and capabilities of the region. The regional authority is a logical consequence to achieve the effectiveness of service management, as well as a responsibility that should be implemented earnestly by the local government. This shows the magnitude of the role of local government in providing services in the field of health so there should be the efforts of local governments to improve the quality of health services.

\section{References}

Azwar, A. (1996). Introduction to Health Administration. Binarupa Script: Jakarta. 


\section{Macrothink}

Journal of Social Science Studies

ISSN 2329-9150

2017, Vol. 4, No. 2

Dwiyanto, A. (2006). Achieve Good Governance through Public service. Gajah Mada University Press: Yogyakarta.

Frederickson, G. (1988). New State Administration (translation). LP3ES: Jakarta.

Jha, S. N., \& Marthur, P. C. (1999). Decentralization and Local Politics: Reading in Indian Government and Politics-2. New Delhi London: Sage Publications.

Muluk, M. R. K. (2007). Decentralization and Local Governance. Malang: Bayu media Publishing.

Pasolong, H. (2007). Theory of Public Administration. Bandung: Al Fabeta. Sekeon, Sekplin USA, 2004. Overview of Health Services at Work Area.

Sinambela, L. P. (2007). Reform of Public Services (Theory, Policy and Implementation). Jakarta: PT earth Script.

Supriyono, B. (2002). Role of Local Government Public Service Quality Improvement. Scientific Journal of Public Administration, 2.

Stewart, J. (1995). Understanding The Management of Local Government: Its Special Purposes, conditions and Tasks. Pitman Publishing: London.

\section{Copyright Disclaimer}

Copyright for this article is retained by the author(s), with first publication rights granted to the journal.

This is an open-access article distributed under the terms and conditions of the Creative Commons Attribution license (http://creativecommons.org/licenses/by/3.0/). 